\title{
Indonesian migrant workers in Hong Kong: Smartphone culture and activism
}

\section{Buruh migran Indonesia di Hong Kong: Budaya ponsel pintar dan aktivisme}

\author{
Irfan Wahyudi ${ }^{1 *} \&$ Panizza Allmark ${ }^{2}$
}

${ }^{1}$ Department of Communication Science, Faculty of Social and Political Sciences, Universitas Airlangga ${ }^{2}$ Department of Media and Cultural Studies, School of Arts and Humanities, Edith Cowan University Address: ${ }^{1}$ Jalan Dharmawangsa Dalam, Airlangga, Surabaya, East Java, Indonesia 60286

2270 Joondalup Dr, Joondalup, Western Australia, Australia 6027

E-mail: irfan.wahyudi@fisip.unair.ac.id*\& p.allmark@ecu.edu.au

\begin{abstract}
This article focuses on contemporary smartphone culture and activism performed by female Indonesian migrant domestic workers in Hong Kong. There are around 330.000 migrant workers in Hong Kong, and wherein 150.000 originated from Indonesia. Most of the Indonesian migrant workers in Hong Kong work in the domestic sectors: housemaid, babysitter, and career. They are obliged to live with their employer and start working from five mornings until late at night for six days a week. The smartphone is their primary medium in keeping a connection with friends and families back home and reduces social isolation. Interestingly, Indonesian migrant workers also use smartphones for activism to support migrant workers' rights issues. Despite the isolation issues and the social limitations experienced by the Indonesian migrant workers', this article aims to explore the following questions: how is smartphone culture developed in Indonesian migrant workers' communication activities in Hong Kong? How is the smartphone, in particular, used as the medium for activism? Using the netnography method, this research explores the smartphone culture and activism performed by Indonesian migrant workers' in their online routine. Smartphone usage has become an interesting phenomenon where this device has changed the cultural habits and further forms a new cultural pattern. Social media platforms and chat applications on smartphones have facilitated Indonesian migrant workers' more comprehensive access to information. It is found that social media access is essential for Indonesian migrant workers to ease loneliness and further used as their medium of existence in the virtual world. Furthermore, they also create virtual identities through social media, share experiences and views through online platforms, and organize protests or other forms of activism. Sulistyaningsih's case is a clear example of how communication access was crucial for Indonesian migrant workers at a time of danger. The diverse forms of communication technology have allowed them to create compelling messages. This activity provides evidence that Indonesian migrant workers still can be creative despite their long working hours.
\end{abstract}

Keywords: migrant; Indonesia; Hong Kong; culture; smartphone; activism; netnography

Abstrak
Tulisan ini berfokus pada budaya ponsel pintar dan aktivisme di kalangan Buruh Migran Indonesia (BMI)
yang bekerja di Hong Kong. Terdapat sekitar 330.000 buruh migran di Hong Kong, dimana sekitar 150.000
berasal dari Indonesia. Sebagian besar BMI di Hong Kong bekerja di sektor domestik menjadi: pembantu
rumah tangga, menjaga anak kecil atau bayi, dan mengasuh orang tua. Mereka diwajibkan tinggal di
rumah majikan dan mulai bekerja sejak pukul lima pagi sampai dengan larut malam selama enam hari
dalam seminggu. Ponsel pintar adalah andalan mereka untuk tetap terhubung dengan keluarga di kampung
halaman, serta untuk meringankan beban isolasi sosial yang terjadi. Menariknya, BMI juga menggunakan
ponsel pintar untuk melakukan aktivisme mendukung isu-isu hak buruh migran. Terlepas dari permasalahan
isolasi dan keterbatasan sosial yang dialami BMI, tulisan ini ingin menjawab pertanyaan-pertanyaan sebagai
berikut: bagaimana budaya ponsel pintar muncul dalam aktivitas komunikasi BMI di Hong Kong? Bagaimana
ponsel pintar secara khusus dipakai sebagai medium aktivisme? Menggunakan metode netnografi, tulisan
ini menelusuri budaya ponsel pintar dan aktivisme oleh BMI dalam aktivitas keseharian secara daring.
Penggunaan ponsel pintar telah menjadi sebuah fenomena yang menarik dimana alat ini telah mengubah
perilaku budaya dan lebih jauh membentuk pola budaya baru. Platform sosial media dan obrolan pada
ponsel pintar telah memungkinkan BMI mendapatkan akses informasi yang luas. Ditemukan bahwa akses
medial sosial penting bagi BMI untuk mengurangi rasa kesepian dan lebih jauh digunakan sebagai sarana
eksistensi di dunia maya. Lebih jauh, mereka juga menciptakan identitas maya, berbagi pengalaman dan


pandangan melalui platform daring, sekaligus mengorganisir aksi protes dan bentuk aktivisme yang lain. Kasus Sulistyaningsih adalah contoh jelas bagaimana akses komunikasi sangat krusial bagi BMI di saat yang membahayakan. Bentuk komunikasi yang beragam telah memberi peluang bagi mereka untuk membuat pesan yang efektif. Aktivitas ini menyediakan bukti bahwa BMI mempunyai kemampuan untuk melakukan aktivisme disela jam bekerja yang panjang.

Kata kunci: migran; Indonesia; Hong Kong; budaya; ponsel pintar; aktivisme; netnografi

\section{Introduction}

Communicating through smartphones is a natural for Indonesian migrant workers or Buruh Migran Indonesia (BMI) abroad. This way of communicating is essential for Indonesian migrant workers' who mostly work as domestic helpers. They need social support to stay connected with their families back home. Indonesian migrant workers work from five until late at night, for six days a week. They use smartphones to serve their daily communication needs and to ease the burden of social isolation. Moreover, Indonesian migrant workers also conduct activism and coordinate through smartphones to demand the fulfillment of their rights as workers. This paper discusses the culture of using smartphones by Indonesian migrant workers working in Hong Kong concerning their communication patterns with families and the interactions of Indonesian migrant workers' with the migrant worker community regarding activism.

The development of social media platforms and chat applications has made it easier for Indonesian migrant workers to communicate and gain broad access to information, even though their work is isolated at their employers' homes. The interactive features embedded in the application have also made it easier for Indonesian migrant workers' to get information related to demands for improving wage standards and protection of migrant workers in Hong Kong. Interactivity via the Internet embedded in smartphones facilitates passive involvement, which is a character of Indonesian migrant workers', especially in their job. Some theorists considered this kind of passive contribution useless (Mozorov 2009). However, according to Cammaerts et al. (2013), passive participation is appropriate for those who are limited in their daily activities to engage in activism, to be involved, to show support and to make donations, which directly serve as a contribution to activists' legitimacy. Migrant workers can passively participate in activism without leaving their jobs. Especially on holidays, they can be directly involved and participate in activism agendas

The use of smartphones has become an interesting phenomenon where this tool has altered cultural behavior and further shaped new cultural patterns (Goggin 2006). For Indonesian migrant workers' in Hong Kong who use smartphones as their communication medium with the world outside, their employer's home is not an exception. Social media platforms and chat applications embedded on smartphones have made it easier for them to communicate and gain broad access to information. Apart from the problem of isolation and social limitations, this paper wants to answer the following questions: how did smartphone culture emerge in Indonesian migrant workers' communication activities in Hong Kong? How was a smartphone used explicitly as a medium of activism? Researchers have specifically discussed issues related to Indonesian migrant workers in Hong Kong in their writings (Anggraeni 2006, Constable 1997, 2007, 2009, 2014, Sim 2002, 2007). In addition, there has been a broader discussion on migration and the media delivered by Alonso \& Oiarzabal (2010) and Madianou \& Miller (2012) with diverse perspectives. However, only a few researchers have explored the issue of migrants from the perspective of media and cultural studies (Allmark \& Wahyudi 2016, 2019, Wahyudi 2018). This paper adopts an essential position in exploring smartphone culture and activism with Indonesian migrant workers' daily activities in Hong Kong explicitly.

\section{Research Methods}

Qualitative methods are used in this study. Furthermore, the researchers used a netnographic approach (Kozinets 2010). Netnography was born as a response to the use of ethnography in cyberspace. The conventional definition of Atkinson \& Hammersley (1994) about ethnography was applied to 
this study: Ethnographic researchers participate, directly or indirectly, in people's daily lives in a certain period, see what happens, hear what is said, ask questions; even collect whatever data are available to get enlightenment from the problem the researcher is looking at. However, this research seeks to explore the smartphone culture within Indonesian migrant workers. It required a strategy, so the netnographic approach by Robert Kozinets was chosen as the research instrument. Kozinets stressed that netnography could explore communication in cyberspace (especially social media, chat rooms, websites, and blogs), which is different from face-to-face communication (Kozinets 2010). Researchers from various disciplines, such as sociology, psychology, education, media, and cultural studies, have used netnography in studying online activities (Bengry-Howell et al. 2011, Costello 2009, Kulavuz-Onal \& Vasquez 2013, Uridge 2014). From 2013 to 2016, the authors made online observations through social media and chat applications, as well as in-depth interviews with Indonesian migrant workers' working in Hong Kong through virtual communication facilities (chat features on social media and chat applications such as WhatsApp).

\section{Result and Discussion}

\section{Smartphone culture}

Migrant workers in Hong Kong are limited by regulations prohibiting them from living outside their employers' homes. This regulation, known as the 'Live-in Policy,' was implemented since 2003 to restrict migrant workers from doing part-time jobs and to protect local workers (Siu 2014). Through the implementation of this regulation, Indonesian migrant workers' were restricted from accessing outside the employer's house. Meanwhile, the geographical distance with their families was also a mental burden. Constable (2014) said that Indonesian migrant workers faced a dangerous situation of trauma because they were physically separated from their families. Social and cultural alienation, as well as the conditions of homesickness, have been experienced by Indonesian migrant workers'. The development of communication technology through smartphones has allowed Indonesian migrant workers' to tackle this condition. Before smartphones, Indonesian migrant workers' had difficulty in maintaining communication, especially with families in Indonesia. As stated by one migrant activist in Hong Kong, LE stated:

\footnotetext{
"I was unable to access communication technology when I first arrived in Hong Kong in 1999. I got my first cell phone (mobile phone) two years later, but I could only use it to call and send messages (SMS). Therefore, there were limitations in communication and expression. Now, I feel that technological innovation has covered that limitation. Separating distance is no longer a problem."
}

The innovation of communication technology gave Indonesian migrant workers more choices, especially in social involvement. Nowadays, Indonesian migrant workers' have more ways to update experience in using technology, especially since smartphones were introduced. As explained by Brunwasser (2015), smartphones are one of the three essential materials for 21st-century migrants, in addition to food and shelter. Research conducted by Madianou (2014) on migrants from the Philippines in the United Kingdom found that smartphones were treated as an opportunity to communicate which acts as a medium to channel emotions and maintain their relationships with families in the Philippines. Furthermore, Filipino migrant workers depended on smartphones to support their online activities, where social media was the most significant portion of their 'alwayson' culture (Madianou 2014). Similarly, for Indonesian migrant workers in Hong Kong, the use of smartphones was also an essential part of their lives abroad.

Globally, smartphone usage has become a part of daily activity. According to the Ericsson (2015) in 2015, there were 3.4 million smartphone users, and in 2020, 70 percent of the world's population has used a smartphone. Goggin (2011) stated that mobile technology, the Internet, and smartphone computation had created captivating features on applications. According to Goggin (2011), these applications are a new cultural platform that has written down metamorphosis in our insights toward mobile phones and media. Smartphone applications enable achievements that were never previously associated with a mobile phone. 
As a functional feature in smartphones, applications have helped Indonesian migrant workers not only receive calls and messages but also in many activities that do not require them to leave work. Such as listening to music and watching content on YouTube. Boredom during work can be overcome with a variety of entertainment and game applications. Maintaining relationships with friends, lovers, or family became more accessible and more interesting because Indonesian migrant workers' had access to social media. According to Madianou \& Miller (2012), the use of technology for communication with families for migrants is significant. Communication technology enables intensive childcare patterns where migrant mothers spend time, energy, and large funds to raise their children (Madianou \& Miller 2012). Madianou \& Miller (2012) stated that smartphones with Internet access had made the 'childcare experience' more complete. Despite promoting the use of communication technology for migrant workers, Madinou \& Miller (2012) also stated that the use of communication technology does not necessarily provide a solution to the distance between migrant mothers and their families at home:

"On the contrary, this (use of communication technology) can increase problems, or often increase the potential for conflict. In the past, as communication was rarely done and not multi-platform, it was easy to maintain expectations, in contrast to now, where communication is constant and interactive, not only with children but also with other family members or even with neighbors who can quickly know family problems because they are shared through social media."

According to Madianou \& Miller (2012), the pattern of migrant worker relations does not depend on just one technology, but on a plurality of media that supports one another and can help overcome the shortcomings of other media. Indonesian migrant workers' can hear the voice of their loved ones and share moments through pictures and video calls. The use of social media through smartphones is also an activity favored by Indonesian migrant workers'. Facebook is a popular social media among Indonesian migrant workers' in Hong Kong. LE said that most Indonesian migrant workers' in Hong Kong use Facebook for their daily needs. LE explained:

"We access our smartphone only to access Facebook, even while working because our family and friends also use it, and we want to know their condition as often as possible."

Indonesian migrant workers' habit of using Facebook is not surprising because Indonesia is the fourth largest in the number of Facebook users with 60.3 million accounts (Statista 2015). According to Marichal (2012) that Facebook became famous because this platform had changed the paradigm of Internet use:

"Instead of seeing the web as a place for anonymous users where each account can have
multiple identities, Facebook connects public and private. Users are encouraged to use their
real names and share real stories about their lives. It helps explain how this site is so popular."

Furthermore, according to Kramer \& Winter (2008), account users use Facebook as a means of social communication to support their identity, maintain relationships, and be a personal archive. In the case of Indonesian migrant workers', they build digital footprints through Facebook so that they can always be socially connected and breakthrough their workplaces' isolation. Indonesian migrant workers' are progressively building and expanding access through social media from their smartphones. It is useful in getting rid of loneliness when working at the employer's house, social media can also be used to disseminate information related to migrant workers' human rights advocacy. However, migrant worker activism also faces various challenges related to their active participation in cyberspace.

According to LE, chairperson of Indonesian Migrant Alliance Against Overcharging or PILAR, Facebook makes it easy for organizations and their members to gather and coordinate actions virtually. However, Indonesian migrant workers tend to focus on "The Facebook reality" and bring personal issues to organizational meetings. Satirical comments on Facebook will be associated with real-life insults and have real-life consequences. LE said that she communicates with members of 
the organization through social media, especially in terms of sharing information and promoting the rights of migrant workers. LE's status uploaded on Facebook often ignited discussions and debates between members that would end in conflict. The dispute occurred because of comments on Facebook and was not quickly resolved. According to LE:

"PILAR has mediated the conflict between Facebook users and PILAR administrators several times. Facebook users tend to be easily offended by an upload. When offended, they immediately engage in confrontation. Therefore, I advise the members of PILAR that if they want to criticize an issue, then just write it down and read it out during an organizational meeting. Instead of doing this (writing on Facebook) and looking down on each other, which is very unproductive. However, I realize that this is difficult to control. When I have succeeded in reconciling, a negative attitude reappears and it continues to recur. To be honest, this situation undermines the organization's program."

Furthermore, LE said that communication technology helped Indonesian migrant workers' to reduce loneliness. Quoting the famous saying of Rene Descartes "cogito ergo sum” (I think, therefore I am), LE described:

"Indonesian migrant workers' now tends to think that as they are active on Facebook, therefore they are."

Madianou (2014) gave a similar example when examined a group of migrant workers in the United Kingdom. Madianou (2014) found that migrant workers, especially those working in the domestic sector, tended to exploit their smartphones to channel expressions and emotions as well as to maintain relationships. Similarly, migrant workers whose work is isolated from the outside world possess very limited personal space in their employers' house. They do not have the opportunity to share their stories with friends and family freely. Long working hours prevent them from meeting friends in person, sharing their feelings and daily experiences.

According to Chou \& Edge (2012), Facebook has provided a platform for individuals to control others' impressions of them. The Indonesian migrant workers' will use their time to make their Facebook accounts interesting. To achieve this, Indonesian migrant workers use various methods to enhance their self-image and tempt other users to visit their Facebook page. They upload the best photos and wait for comments or feedback from other users, then replace or rearrange the post and upload them again. Through this activity, Indonesian migrant workers' may be isolated at work, but they can improve their public image through Facebook. Even though it seems fake, it is essential for Indonesian migrant workers' to create a positive impression of themselves through social media, because this can be the only way for them to socialize with the outside world. The Indonesian migrant workers choose to channel their feelings through Facebook because they have limited options for self-actualization. They use Facebook as a medium to share their feelings from day today. According to Walther et al. (1994), for isolated individuals like Indonesian migrant workers', they had lost nonverbal signs in social interaction. In this case, Facebook has the potential to disrupt the process of interaction. However, social media has become a good friend of Indonesian migrant workers' in overcoming loneliness, despite the harmful impact of technology on daily life and work. Virtual activities reduce their concentration on work, affect emotions, and make them vulnerable to threats, fraud, and extortion. Some cases of fraud and extortion are as explained by DG:

\footnotetext{
"Many Indonesian migrant workers do not understand the risk of communication through cyberspace. I have an Indonesian migrant worker friend who is in a relationship with a man from Taiwan, where they met on Facebook. She never met this man, but she wanted to send her nude photos. When they broke up, my friend finally learned the man's identity when her nude photo was used to blackmail her. The man asked for a ransom, otherwise, the photo would be posted on the Internet. Another Indonesian migrant worker was asked by her boyfriend to take pictures of her employer's credit card and identity and was promised to pay for the Indonesian migrant workers' insurance. A month later, some money was deducted from her employer's credit card
} 
and was apparently used for online shopping by foreign users. The Indonesian migrant workers were reported to the police and were suspected of being part of a cybercrime group. However, the Indonesian migrant workers did not understand the consequences of her mistakes."

Indonesian migrant workers knowledge and vigilance against the dangers of social media remains alarming. As stated by LE:

"We only know that smartphones can be used to access social media. We are entertained by social media and are not vigilant if anyone uses us. We do not have enough knowledge about cyberspace risks."

Although Indonesian migrant workers enjoy interaction through social media, they are not aware of the potential damage. As explained by Trevathan \& Myers (2012), Facebook has created opportunities for abused Indonesian migrant workers, resulting in identity theft, identity misrepresentation, cyberbullying, and fraud. For example, identity theft can be quickly done by observing someone's Facebook profile, and identity theft nowadays often started with social media. Many Indonesian migrant workers now voluntarily share personal identities, such as workplace addresses and photos. It is due to their need for recognition from friends on Facebook, which, unfortunately, puts them in potential danger. Furthermore, Benotsch et al. (2012) found that interacting through social media affected health, which, for Indonesian migrant workers, is crucial as their work requires excellent physical health.

The broader community accepts social media as a means of communicating, sharing information, and maintaining relationships between people. Almost all Indonesian migrant workers interviewed in Hong Kong said that they access social media daily, both at work and at rest. They upload their status through Facebook about what they think is being done, share sad and funny stories, continue the agenda of migrant organizations, give comments or 'thumbs up' to their friends' Facebook status. It was done to maintain connectedness and reduce feelings of social bondage and loneliness (Deter $\&$ Mehl 2012). Indonesian migrant workers' usually access Facebook through smartphones, and DG stated:

"When accessing Facebook, they do it secretly because Facebook only needs the ability to write."

Other Indonesian migrant workers have developed strategies to keep accessing Facebook while working, $\mathrm{H}$ said:

"I used the strategy by pretending to go to the toilet. I locked the toilet door from the inside for a few minutes, and updated my status, read my friends' status, and made comments."

Some Indonesian migrant workers try to make sure that their employers do not know that they access Facebook. If the employer found out that they accessed the smartphone and did not do their job, they could immediately be fired. However, Indonesian migrant workers' ignored the threat and continued to access Facebook.

Regarding the habit of using Facebook, an Indonesian migrant worker' named ED said that she uses Facebook to share online news links about migrant workers and human rights. ED, using Facebook, is a form of entertainment for Indonesian migrant workers'. She uses Facebook to see the condition of her family through photos and posts uploaded by her beloved family. Interaction with the world outside the employer's house is vital for Indonesian migrant workers' like ED and is facilitated through Facebook. According to Andreas (2007), social media is operates as an interdependent factor for grassroots communities where its sustainability can be made possible through interaction and participation. By accessing Facebook, ED can reduce the loneliness she feels while interacting with the migrant worker community. ED also realized that social media has negative impacts, and stated: 
"Using social media is good as long as you understand the limits, but actually, Facebook is addictive and cannot make you sleep peacefully."

'Addiction' is a word to describe the use of Facebook by Indonesian migrant workers', for example, SY (2013) said that she used Facebook to relieve homesickness, but, as a result, she used Facebook continuously. SY (2013) said:

"I occasionally access Facebook while working, but at night I play Facebook until morning that I do not have enough time to sleep."

However, there are Indonesian migrant workers' who choose not to access Facebook because it is not essential. There were Indonesian migrant workers' who claimed not to use Facebook. HY said that she chose to use WhatsApp, Viber, and WeChat, especially in communicating with her boyfriend. She stopped using Facebook because her friends left rude comments on her status. HI gave a different perspective, saying that she did not use Facebook because she did not know how to use it:

"I cannot read small letters. In addition, I only need to contact my family by telephone."

In line with HI, SU (2013) argued:

"I just thought of how to send money home. There is no time for social media."

SU (2013) and HI believed that they communicate well with their families by using conventional techniques such as telephone and SMS. The variations in the use of smartphones by Indonesian migrant workers' for communication purposes with the world outside their workplaces have provided a clear picture of how smartphone culture has been widely implemented. Indonesian migrant workers' need to stay connected with their relatives and friends has become the core foundation of smartphone culture. It ultimately provides benefits for previous generations of Indonesian migrant workers who did not know about smartphones as a medium of communication. One of the advantages is the ability of Indonesian migrant workers' to be able to organize themselves and carry out activism.

\section{Activism by Indonesian migrant workers}

The development of communication technology has brought benefits to handling migrant worker cases. As more Indonesian migrant workers have smartphones, case reporting has become more efficient. This condition is different from twenty years ago. According to LE, in early 2000, cases of abuse and low salary were not usually reported due to the lack of channels. The technology embedded in smartphones allows Indonesian migrant workers' to report bad situations they experience and get a response from the authorities in Hong Kong.

The use of a smartphone or cell phone is vital for migrant workers, especially during emergencies and dangers. AS, a migrant worker from the Philippines who fled to a shelter, Bethune House, said that her employer tortured her, but could not report it because she was not allowed to leave the house, and did not have access to communication. AS stated:

"My agent forbade me to bring my cell phone to the employer's house. I had a problem with my employer. On the third day of work, my employer hit me. I did not have a cellphone and could not use the home phone because my employer hid it. I could not tell my friend because I was not allowed to leave the house, I was very sad; there were no friends to share and complain. I did not have money. I worked for another month, then I ran away from my employer's house and accommodated in Bethune House until now."

AS' experience is strong evidence of how cellphones play an essential role in migrant workers. Indonesian migrant workers are left alone and vulnerable without any media to report emergencies and dangerous conditions that they experience without cellphones or smartphones. Mobile phones can be used to report harassment by collecting visual evidence using a mobile phone's camera and sending it to friends, migrant organizations, or lawyers through the chat application. 
In the Middle East, it was reported that the majority of migrant workers are prone to violence in their workplace, including physical, sexual, and psychological violence (Human Rights Watch 2014). Having a cellphone is crucial for Indonesian migrant workers' because they most likely need to communicate their conditions at work. Human Rights Watch (2014) reported that one of the main reasons migrant workers are tortured is because their employers feel that they own the workers and after all, they have paid some money, it is a form of slavery. (Human Rights Watch 2014) reported:

"Some workers said that their employers had beaten them so that they could work harder.

Moreover, they were afraid to tell (about it)."

The same thing happened to Erwiana Sulistyaningsih in 2014. The revelation of the Sulistyaningsih case was evidence of the strong spirit of activism in the Indonesian migrant workers community in Hong Kong.

\section{Sulistyaningsih case}

Sulistyaningsih's torture may not be the worst in the history of Indonesian migrant workers' journey abroad. There had been several torture cases involving Indonesian migrant workers, but the Sulistyaningsih case attracted the attention of international mass media due to a massive campaign of migrant activists mainly through social media such as Facebook. In Indonesia, the Sulistyaningsih case was the main feature of newspapers and electronic media. Global mass media such as CNN, BBC, and Al Jazeera also made special editions on the case. In April 2014, TIME magazine even named Sulistyaningsih as one of the 100 Most Influential People in 2014 (Mam 2014).

Excellent media attention toward the case would have never appeared without the active participation of Indonesian migrant workers' through Facebook. They shared information so that the case was thoroughly revealed. They shared information and news links related to Sulistyaningsih from both the Hong Kong and Indonesian media and reposted press releases from migrant organizations related to the case. An online campaign also occurred in 1998 related to racial riots in Jakarta. A group named Huaren, as explained by Meikle (2002), covered the riots in Jakarta, so it received global attention, especially about violence against those of Chinese descent. In the Sulistyaningsih case, the use of communication technology, mainly with social media, reached a wider audience than what Huaren did in 1998.

Indonesian migrant workers' active participation through their smartphones was the supporting factor to the enormous attention to the Sulistyaningsih case. Sulistyaningsih first met Yanti, Indonesian migrant workers, at Hong Kong International Airport on January 9 before midnight. Yanti was on her way home after her work contract had completed in Hong Kong. Sulistyaningsih, at that time, as described by Yanti in Wismabrata (2014), had a bruised face and burnt-like skin condition:

"I never knew this woman, I asked what happened, but she only said it was a skin disease."

Yanti in Wismabrata (2014) did not believe the story and forced Sulistyaningsih to be honest:

"Then Sulistyaningsih said she had been beaten by her employer and was threatened not to talk to anyone about it or else her employer would kill her family in Indonesia."

Yanti then took a picture of Sulistyaningsih and sent it to her friends. One of her friends then sent it to Yuni Tze, an Indonesian media journalist in Hong Kong who later uploaded the photo to Facebook and tagged migrant activists, one of whom was LE. The photo uploaded onto Facebook went viral and was shared more than one hundred times in an hour after being uploaded. On January 14, 2014, a Facebook account was created to support Sulistyaningsih, which reached thousands of likes in minutes. The account name was Justice for Erwiana Sulistyaningsih, which presented information in Indonesian, Cantonese, and English. The account served as a reference for anyone who sought information on the progress of Sulistyaningsih 's case, ranging from Sulistyaningsih's health condition and the arrest of her employer to the prosecution of the employer by the Hong Kong court. 
The Facebook account also increased the vigilance of Indonesian migrant workers in Hong Kong, ranging from information about what could happen to them to the demand for street protests in Hong Kong to raise Hong Kong citizens' awareness about the safety of migrant workers. Thousands of migrant workers carried out demonstrations. They marched together to the office of the Hong Kong Legislative Body and the Chan's Asia Recruitment, the employment agency in Hong Kong, which recruited Sulistyaningsih. They demanded the Hong Kong government pay serious attention to Sulistyaningsih's case and immediately close down the agencies involved. A dance movement called 'One Billion Rising' was performed en masse in a large field in Victoria Park, Hong Kong. Local Hong Kong residents, activists, and migrant workers attended the event from various countries. This event was held to support Erwiana and as a campaign to stop violence against women (Ngo 2015). The activity was an outstanding example of how social media has been used for severe purposes in the campaign of migrant issues in Hong Kong. Activism was effective because activists used social media to gather masses and took concrete actions involving the wider community.

Indonesian migrant workers groups and organizations used social media comprehensively. AR, an activist at Mission for Migrant Workers (MFMW), said that her organization was accustomed to sharing information via Facebook. Through Facebook, the organization invited Indonesian migrant workers to come to meetings on holidays, organize campaigns and plan demonstrations on the streets of Hong Kong. S, a member of IMWU, explained that she uses Facebook not only to disseminate information but also to coordinate with IMWU members through Facebook messenger. Indonesian also uses platforms other than Facebook. Indonesian migrant workers' in Hong Kong who use Twitter are mostly serious about writing and possess a particular interest in exploring various social media platforms. Some used Twitter to express their opinions and to communicate with government officials. N, for example, actively used Twitter. When the Sulistyaningsih case surfaced in early 2014, she contacted the Twitter account of the Indonesian Minister of Manpower and Transmigration, Muhaimin Iskandar. N asked whether Muhaimin knew and understood the situation of Sulistyaningsih's case. Muhaimin then replied that he did not know and asked $\mathrm{N}$ to explain further. $\mathrm{N}$ said:

"After our conversation on Twitter, Minister Muhaimin asked his staff to follow up and assist Sulistyaningsih."

$\mathrm{N}$ actively uploaded tweets about Sulistyaningsih's latest updates and was contacted several times by journalists in Indonesia to discuss the case. The activism carried out by $\mathrm{N}$ on Twitter is a valuable example of how Indonesian migrant workers' can actively participate through social media other than Facebook. Social media is a powerful communication tool for activism that can be used as a broadcasting medium, helps them (activists) to spread information about their cases, and reduces their involvement in the mainstream media (Kavada 2013).

YouTube is another form of social media used by Indonesian migrant workers' in their activism; they upload videos of their activities, especially when they are in action. Sringatin, IMWU chairperson uploads videos to her personal YouTube account. She uploads edited and unedited videos about seminars, demonstrations, workshops, advocacy, and other activities in Hong Kong through her Katon Jinawi account. The Indonesia Migrant Worker Alliance (ATKI) organization also uploads videos of their activities to YouTube. Indonesian migrant workers' activities via YouTube are what Turnsek \& Jankowski (2008) referred to as the YouTube-ification of politics, where accessible virtual space is used as an essential arena in political communication. The use of YouTube is described by Uldam \& Askanius (2013) as the visual revolution shock and the beginning of a new era of digital video culture. YouTube has contributed significantly to transformation in egalitarian political discourse that facilitates freedom of expression without the supervision of the elites (Uldam \& Askanius 2013).

\section{Conclusion}

There are many advantages gained by Indonesian migrant workers' when they have access to a smartphone. Online activities on social media via smartphones have provided the opportunity to interact with family at home and fellow migrant workers. The use of smartphones also gives strength to Indonesian migrant workers' by providing a platform to socialize with migrant workers' 
communities, groups, and organizations. The smartphone culture of Indonesian migrant workers in Hong Kong has fulfilled the need for connectivity and enabled the use of various new media platforms. The specific experiences of migrant workers in using smartphones provide concrete evidence that the implementation of communication technology is crucial to the migrant worker community. More specifically, Indonesian migrant workers' unique position of being distant from home has initiated new definitions of activities that did not occur before the smartphone era. Among them is the ability of Indonesian migrant workers' to make virtual contacts easily with families, create virtual identities through social media, share experiences and views through online platforms, and organize protests or other forms of activism.

Online activism by Indonesian migrant workers' is done through various platforms (Facebook, YouTube, Twitter, WhatsApp), which has enriched their experience with technology, something they might not get at home. Examples of smartphone usage by Indonesian migrant workers provided strong evidence of how communication technology was crucial for their lives, wherein they spent most of their time in employers' homes with long working hours. Sulistyaningsih's case is a clear example of how communication access was crucial for Indonesian migrant workers at a time of danger. In addition, the power of social media in the Sulistyaningsih's case also proved that messages spread quickly; in other words, 'to be viral.' Justice for Erwiana Sulistyaningsih's account's updates on Sulistyaningsih's case became a source for media and served as a shred of reliable evidence that activism can be carried out by Indonesian migrant workers' whose lives are isolated.

However, social media could also bring negative consequences for Indonesian migrant workers', especially those who are new to these virtual platforms. Disputes and conflicts can start from status and comments uploaded on Facebook. It has led activists and leaders of organizations to rethink their social media strategies as a means of activism. On the other hand, the diverse forms of communication technology have allowed Indonesian migrant workers' to create useful messages. This activity provides evidence that Indonesian migrant workers' still have the energy to be creative despite their long working hours.

\section{References}

Allmark P \& Wahyudi I (2016) Female Indonesian Migrant Domestic Workers in Hong Kong: A Case Study of Advocacy through Facebook and the Story of Erwiana Sulistyaningsih. In: Gomes C (ed). The Asia Pacific in the Age of Transnational Mobility: The Search for Community and Identity on and through Social Media. London: Anthem Press.

Allmark P \& Wahyudi I (2019) Travel, sexuality and female Indonesian domestic migrant workers in Hong Kong. Continuum Journal of Media and Cultural Studies 33 (5):630-642. https://doi. org/10.1080/10304312.2019.1652042.

Andreas CS (2007) Web 2.0 and the culture-producing public. [Accessed 20 June 2014]. https:// www.scribd.com/doc/40127/Web-2-0-and-the-Culture-Producing-Public.

Anggraeni D (2006) Dreamseekers: Indonesian Women as Domestic Workers in Asia. Jakarta: Equinox Publishing.

Alonso A \& Oiarzabal PJ (eds) (2010) Diasporas in the New Media Age: Identity, Politics, and Community. Nevada: University of Nevada Press.

Atkinson P \& Hammersley M (1994) Ethnography and Participation Observation. In: Denzin NK \& Lincoln YS (eds). Handbook of Qualitative Research. California: Sage Publication. 248-261.

Bengry-Howell A, Wiles R, Nind M, \& Crow G (2011) A Review of the Academic Impact of Three Methodological Innovations: Netnography, Child-Led Research and Creative Research Methods. NCRM Working Paper Series. National Centre for Research Methods. Unpublished. [Accessed 20 August 2015]. http://eprints.ncrm.ac.uk/1844/1/Review_of_methodological_ innovations.pdf.

Benotsch EG, Snipes DJ, Martin AM, \& Bull SS (2012) Sexting, substance use, and sexual risk behavior in young adults. Journal of Adolescent Health 52 (3):307-313. https://doi.org/10.101 6/j.jadohealth.2012.06.011. 
Brunwasser M (2015) A 21st-century migrant's essentials: Food, shelter, smartphone. New York Times, 25 August. [Accessed 19 February 2016]. http://www.nytimes.com/2015/08/26/ world/europe/a-21st-century-migrants-checklist-water-shelter-smartphone.html.

Cammaerts B, Mattoni A, \& McCurdy P (eds). (2013) Introduction: Mediation and Protest Movement. Bristol: Intellect.

Chou HTG \& Edge N (2012) "They are happier and having better lives than i am": The impact of using Facebook on perceptions of others' lives. Cyberpsychology, Behavior, and Social Networking 15 (2):117-125. https://doi.org/ 10.1089/cyber.2011.0324.

Constable N (1997) Maid to Order in Hong Kong: Stories of Filipina Workers. Ithaca: Cornell University Press.

Constable N (2007) Maid to Order in Hong Kong: Stories of Migrant Workers. Ithaca: Cornell University Press.

Constable N (2009) Migrant workers and the many states of protest in Hong Kong. Critical Asian Studies 41 (1):143-164. https://doi.org/10.1080/14672710802631202.

Constable N (2014) Born Out of Place: Migrant Mothers and the Politics of International Labor. London: University of California Press.

Costello L (2009) Communicating health promotion on the web: The building, functioning and marketing of a therapeutic online community. Unpublished.

Deter FG \& Mehl MR (2012) Does posting Facebook status updates increase or decrease loneliness? An online social networking experiment. Social Psychological \& Personality Science 4 (5):579-586. https://doi.org/10.1177/1948550612469233.

Ericsson (2015) Ericsson Mobility Report on the Pulse of the Networked Society. [Accessed 20 August 2015]. https://www.ericsson.com/assets/local/news/2016/03/ericsson-mobility-repo rt-nov-2015.pdf

Goggin G (2006) Cell Phone Culture: Mobile Technology in Everyday Life. London: Routledge.

Goggin G (2011) Ubiquitous apps: Politics of openness in global mobile cultures. Digital Creativity 22 (3):148-159. https://doi.org/10.1080/14626268.2011.603733.

Human Rights Watch (2014) "I Already Bought You": Abuse and Exploitation on Female Migrant Domestic Workers in the United Arab Emirates. [Accessed 20 August 2015]. https://www. hrw.org/report/2014/10/22/i-already-bought-you/abuse-and-exploitation-female-migrantdomestic-workers.

Kavada A (2013) Internet Cultures and Protest Movements: The Cultural Links between Strategy, Organizing and Online Communication. In: Cammaerts B, Mattoni B, \& McCurdy P (eds). Mediation and Protest Movements. Bristol: Intellect. 75-94.

Kozinets RV (2010). Netnography: Doing Ethnography Research Online. London: Sage.

Kramer NC \& Winter S (2008) Impression management 2.0: The relationship of self-esteem, extraversion, self-efficacy, and self-presentation within social networking sites. Journal of Media Psychology 20 (3):106-116. https://doi.org/10.1027/1864-1105.20.3.106.

Kulavuz-Onal D \& Vasquez C (2013) Reconceptualising fieldwork in a netnography of an online community of English language teachers. Ethnography and Education 8 (2):224-238. https:// doi.org/10.1080/17457823.2013.792511.

Madianou M (2014) Smartphones as polymedia. Journal of Computer-Mediated Communication 9 (3):667-680. https://doi.org/10.1111/jcc4.12069.

Madianou M \& Miller D (2012) Migration and New Media: Transnational Families and Polymedia. London: Routledge.

Mam S (2014) The 100 Most Influential People: Erwiana Sulistyaningsih. [Accessed 20 Agustus 2015]. http://time.com/70820/erwiana-sulistyaningsih-2014-time-100/.

Marichal J (2012) Facebook Democracy: The Architecture of Disclosure and the Threat to Public Life. Farnham: Ashgate Publishing.

Meikle G (2002) Future Active Media Activism and the Internet. New York: Routledge. 
Mozorov E (2009) The internet: A room of our own? Dissent. [Accessed 20 August 2015]. http:// www.evgenymorozov.com/files/09Summer-MorozovInternet.pdf.

Ngo J (2015) Erwiana in one billion rising dance campaign to end violence against women. South China Morning Post, 15 February. [Accessed 20 August 2015]. http://www.scmp.com/news/ hong-kong/article/1713560/erwiana-one-billion-rising-dance-campaign-end-violenceagainst-women.

Sim AS (2002) Organising discontent: NGOs for Southeast Asia Migrant Workers in Hong Kong. Asian Journal of Science 31 (3):478-510. https://doi.org/10.1163/156853103322895351.

Sim AS (2007) Women in transition: Indonesian domestic workers in Hong Kong. Theses, University of Hong Kong, Hong Kong. https://doi.org/10.5353\%2Fth_b3830580.

Siu P (2014) New employee abuse victims emerge as thousands march for justice for Erwiana. South China Morning Post, 19 January. [Accessed 20 August 2015]. http://www.scmp. com/news/hong-kong/article/1408970/new-victims-emerge-maids-rally-justice-erwianasulistyaningsih.

Statista (2015) Number of Facebook users in Indonesia from 2012 to 2015 (in millions). [Acessed 20 August 2015]. http://www.statista.com/statistics/304829/number-of-facebook-users-inindonesia/.

Trevathan J \& Myers T (2012) Anti-social networking? World Academy of Science Engineering and Technology 72:82-90. [Accessed 20 August 2015]. http://www98.griffith.edu.au/dspace/ bitstream/handle/10072/52264/82783_1.pdf?sequence $=1$.

Turnsek M \& Jankowski N (2008) Social media and politics: Theoretical and methodological considerations in designing a study of political engagement. In: Politics: Web 2.0: An International Conference New Political Communication Unit, 17-18 April 2008, London: University of London. https://doi.org/10.2139/ssrn.1629098.

Uldam J \& Askanius T (2013) Online civic cultures? Debating climate change activism on Youtube. International Journal on Communication 7 (2013):1185-1204.

Uridge L (2014) The identity of the heart patient in the context of the gift economy: HeartNET and media framing. Unpublished.

Wahyudi I (2018) Articulating Indonesian migrant domestic workers' activism in Hong Kong and the use of communication technology. In: Urban Studies: Border and Mobility Proceeding of the 4th International Conference on Urban Studies (ICUS 2017), 8-9 December 2017, Surabaya: Universitas Airlangga. https://doi.org/10.1201/9780429507410.

Walther JB, Anderson JF, \& Park DW (1994) Interpersonal effects in computer-mediated interaction: A meta analysis of social and antisocial communication. Communication Research 21 (4):460-487. https://doi.org/10.1177/009365094021004002.

Wismabrata M (2014) Erwiana, TKW asal Sragen disiksa majikan di Hong Kong. Kompas. com, 20 January. [Accessed 20 August 2015]. https://regional.kompas.com/read/2014/ 01/20/1249353/Erwiana.TKW.Asal.Sragen.Disiksa.Majikan.di.Hongkong. 